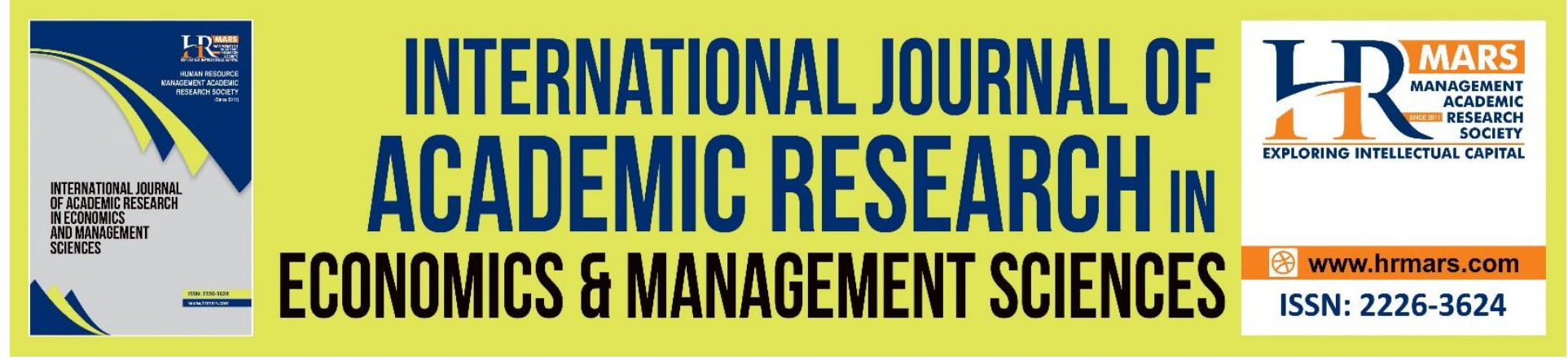

\title{
The Effect of Occupational Health and Safety, Work Accidents and Skills of Construction Workers on the Quality of Life of Construction Industry Workers in Indonesia
}

\author{
Muhammad Ridha Akbar Martiano \& Dan Anton Soekiman
}

To Link this Article: http://dx.doi.org/10.6007/IJAREMS/v10-i1/8868 DOI:10.6007/IJAREMS/v10-i1/8868

Received: 25 January 2021, Revised: 28 February 2021, Accepted: 20 March 2021

Published Online: 31 March 2021

In-Text Citation: (Martiano \& Soekiman, 2021)

To Cite this Article: Martiano, M. R. A., \& Soekiman, D. A. (2021). The Effect of Occupational Health and Safety, Work Accidents and Skills of Construction Workers on the Quality of Life of Construction Industry Workers in Indonesia. International Journal of Academic Research in Economics and Managment and Sciences, 10(1), 72-80.

\section{Copyright: (C) 2021 The Author(s)}

Published by Human Resource Management Academic Research Society (www.hrmars.com)

This article is published under the Creative Commons Attribution (CC BY 4.0) license. Anyone may reproduce, distribute, translate and create derivative works of this article (for both commercial and non-commercial purposes), subject to full attribution to the original publication and authors. The full terms of this license may be seen

at: $\underline{\text { http://creativecommons.org/licences/by/4.0/legalcode }}$

\section{Vol. 10, No. 1, 2021, Pg. 72 - 80}




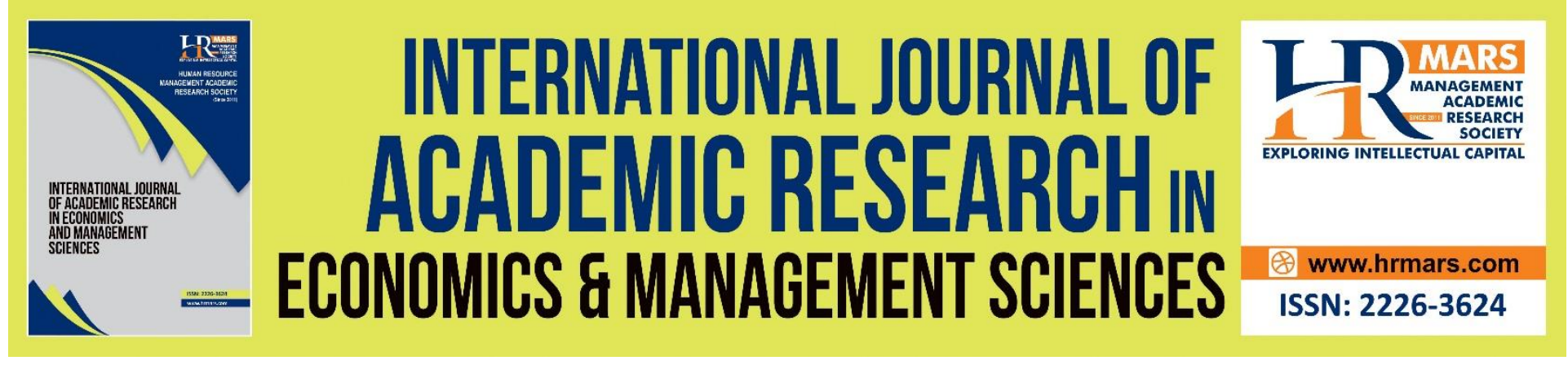

\title{
The Effect of Occupational Health and Safety, Work Accidents and Skills of Construction Workers on the Quality of Life of Construction Industry Workers in Indonesia
}

\author{
Muhammad Ridha Akbar Martiano ${ }^{1}$ \& Dan Anton Soekiman ${ }^{2}$ \\ ${ }^{1}$ Civil Engineering Master's Program, Parahyangan Catholic University, Jl. Ciumbuleuit 94. \\ Bandung, ${ }^{2}$ Faculty of Engineering, Department of Civil Engineering, Parahyangan Catholic \\ University, Jl, Ciumbuleuit 94 . Bandung. \\ Email: muchamadridhaakbar21@gmail.com, soekiman@unpar.ac.id
}

\begin{abstract}
The construction industry in Indonesia is growing rapidly in line with increasing demand and involves many construction workers. The problem faced is that the welfare and quality of life of construction workers is still relatively low and this makes the quality of construction workers in Indonesia also relatively low. One of the reasons is because of the high cost of access and the lack of time and opportunity for these non-formal workers to get education and training in order to improve their skills in the construction sector. The welfare and quality of life of construction workers is also related to Occupational Safety and Health (K3), which in its application in Indonesia by construction companies has not been implemented properly. This study aims to examine the effect of occupational safety and health (K3) in construction, work accidents and construction worker skills on the quality of life of construction workers in Indonesia. The data was collected through a survey of construction workers in West Java, and the analysis was carried out by means of descriptive statistical analysis and inferential statistical analysis.

The results of the analysis show that the worker's perspective on occupational health, work accidents, worker skills and quality of life of workers is at a high level, while the perspective of workers on job safety is at a high enough level. The analysis also shows that the quality of life of construction workers in Indonesia is not influenced by age, experience and type of construction work (structural, architectural, mechanical and electrical). Meanwhile, occupational accidents and occupational health have an effect on increasing the skills of construction workers. The results of the analysis also showed that the health of workers and workers' skills had an effect on the quality of life of construction workers. However, the correlation analysis shows that the relationship between the variables of occupational health factors, workers' skills and work accidents on the quality of life of construction workers has a less significant correlation.
\end{abstract}

Keywords: Construction Workers, Occupational Health and Safety, Work Accidents, Worker Skills, Worker Quality of Life 


\section{Introduction}

Indonesia is a country that has a large population, this is a gift that is not owned by every country. The large number of people accompanied by the large number of workers who need work for a living make this two points of the sword that must be considered.

The low welfare and quality of life of non-formal workers in the construction sector is a part that must be of concern to all parties engaged in the construction sector.

One important aspect that construction management must pay attention to in order to regulate a lot of construction workplaces so that it can be an advantage in construction is the aspect of occupational safety and health which is one of the reference units for construction companies, namely Occupational Health and Safety Assessment.

In its implementation in Indonesia, the Indonesian government has ratified the Occupational Health and Safety Assessment into laws and regulations, namely in the form of occupational safety and occupational health (K3) construction. According to Yuli (2005: 211) occupational health and safety (K3) is an activity that guarantees the creation of safe working conditions, avoids physical and mental disorders through coaching and training, direction, and control of the implementation of duties of employees and providing assistance according to the rules. applicable, both from government agencies and companies where they work. One of the latest regulations issued by the Indonesian government in order to regulate the implementation of K3 in construction activities is PUPR Minister No.2 of 2018 this is the latest reference in implementing K3 in Indonesia. Occupational safety and occupational health (K3) construction in its application in Indonesia by construction companies are still not implemented properly. Many factors cause it, one of which is the non-compliance of field workers in implementing the K3 management system that has been established by the construction company so that frequent work accidents or work diseases that occur in a bad work environment can result in death, or employees may experience temporary disability or illness and cannot work, then the employee concerned is no longer able to work properly or the level of work productivity will decrease compared to healthy time.

This research is a research that looks for the influence of occupational safety and health, work accidents and construction worker skills on the quality of life of construction industry workers in Indonesia. The form of research can be described as follows:

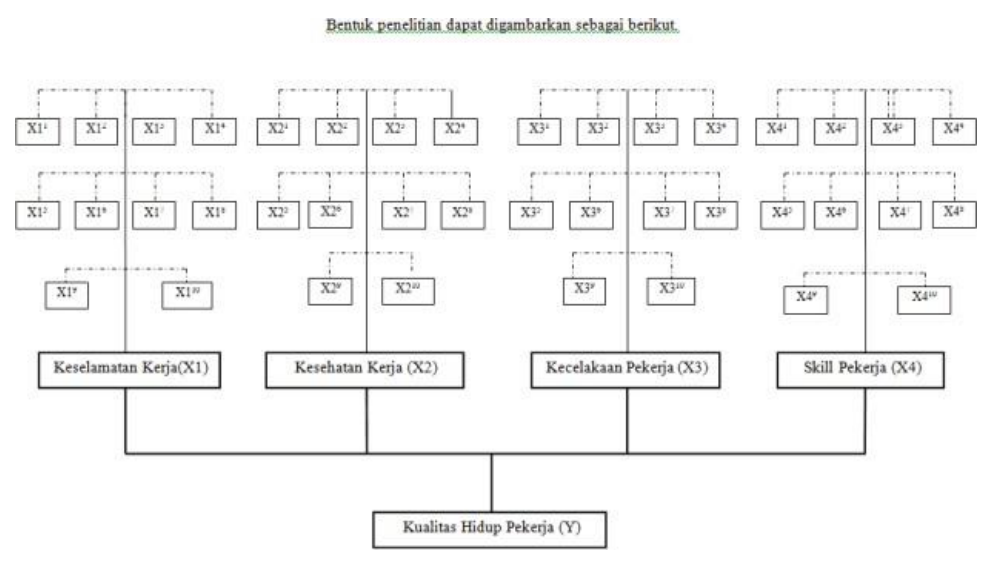

Figure 1. Form of Research 


\section{Explanation:}

$X 1, X 1^{1-10}=$ Independent Variable $X 2, X 2^{1-10}=$ Independent Variable $X 3, X 3^{1-10}=$ Independent Variable $X 4, X 4^{1-10}=$ Independent Variable $Y=$ Dependant Variable

The hypothesis of this research is to determine the assumption of the relationship between the independent and dependent variables, the researcher puts forward the following hypothesis:

HO1 There are no significant differences in the aspects of safety, health, accidents, skills and quality of life among construction workers based on age. .

HO2 There are no significant differences in the aspects of safety, health, accidents, skills and quality of life among construction workers based on work experience.

HO3 There are no significant differences in the aspects of safety, health, accidents, skills and quality of life among construction workers based on the type of construction work.

HO4 There are no significant differences in the aspects of safety, health, accidents, skills on the quality of life among construction workers based on the income of construction workers per week.

HO5 There is no significant effect between safety, health, accidents, skills, on the quality of life among construction workers.

\section{Method}

Research design refers to planning in selecting the research population, research locations and data collection procedures (Gay \& Airasian 2003). This research is a survey research using quantitative data.

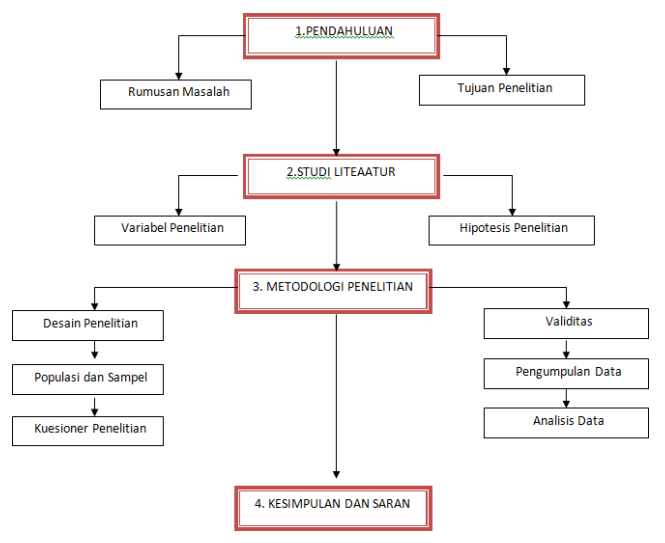

Figure 2. Research Design

In this study, the research sample of Morgan was used to take a sample of 450 people. 


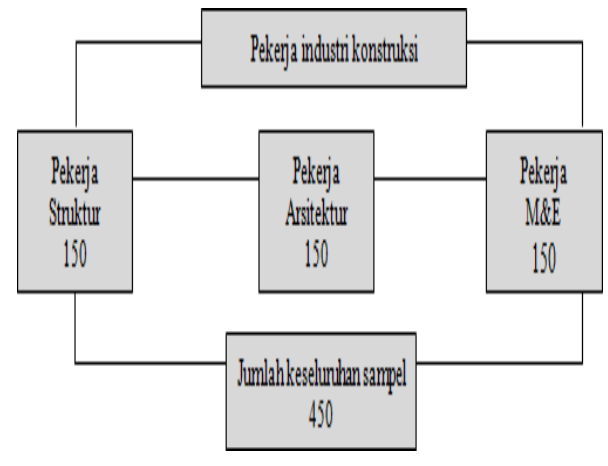

Figure 3. Research Sample

Sampling is a research strategy that allows researchers to obtain information about a population from several individuals who are members of that population (Coakes, 1999). The research instrument used was distributing questionnaires to the predetermined 450 respondents.

The preparation of this questionnaire instrument is based on a combination of theories, models and adaptation of questionnaires related to Occupational Safety and Health (K3) Construction, Work Accidents, Skills and Quality of Life factors. Theories and models used in the construction of this instrument are the Occupational Safety and Health (K3) construction model and QOL Ventegodt Theory, Mohd Majid (2000).

To measure the response of the respondents using a Likert point 5 scale.

\begin{tabular}{|l|r|}
\hline Responds & Scale \\
\hline Strongly disagree & 2 \\
\hline Disagree & 3 \\
\hline Neither agree or disagree & \\
\hline Agree & 5 \\
\hline Strongly agree & \\
\hline
\end{tabular}

The results of the collected data from respondents were analyzed by using descriptive statistics to comprehensively view and describe the respondents, such as gender, ethnicity, socio-economics and even academics. To find the assumptions of each variable, whether it is dependent or independent, two types are used 
Explanation

\begin{tabular}{|l|l|}
\hline $\mathrm{Y}$ & Dependent Variable \\
\hline $\mathrm{a}$ & Constant \\
\hline $\mathrm{b} 1, \mathrm{~b} 2, \mathrm{~b} 3$ & $\begin{array}{l}\text { Regression } \\
\text { Coefficient Value }\end{array}$ \\
\hline $\mathrm{x} 1, \mathrm{x} 2, \mathrm{x} 3$ & Independent Variable \\
\hline
\end{tabular}

ANOVA test to identify differences to find out whether there are differences in occupational safety and health aspects, work accidents, and construction workers' skills on quality of life based on age, experience and type of work.

Multiple regression analysis to determine the contribution of occupational safety and health, work accidents and skills to the quality of life of construction workers in Indonesia. Multiple regression analysis was also conducted to identify the contribution of occupational safety and health, work accidents and skills to the quality of life of construction workers in Indonesia. The multiple regression formula is as follows:

$\mathrm{Y}=\mathrm{a}+\mathrm{b}_{1} \mathrm{x}_{1}+\mathrm{b}_{2} \mathrm{x}_{2}+$ $+b_{n} x_{n}+$

\section{Findings and Discussion}

The collected data were analyzed using descriptive and inferential statistical analysis.

\section{Demographic Profile}

\begin{tabular}{|l|c|c|c|}
\hline Profile & $\begin{array}{l}\text { Demografi } \\
\text { c }\end{array}$ & $\begin{array}{l}\text { Freque } \\
\text { ncy }\end{array}$ & $\begin{array}{l}\text { Percentag } \\
\text { e }\end{array}$ \\
\hline Age & $19-25$ & 85 & 18.9 \\
\hline & $26-31$ & 177 & 39.3 \\
\hline $\begin{array}{l}\text { Experi } \\
\text { ence }\end{array}$ & $32<$ & 188 & 41.8 \\
\hline & $<5$ Year & 255 & 56.7 \\
\hline $\begin{array}{l}\text { Type } \\
\text { of Work }\end{array}$ & $\begin{array}{c}\text { Architectur e } \\
\end{array}$ & 150 & 33.3 \\
\hline & Mechanic & 150 & 33.3 \\
\hline & Structure & 150 & 33.3 \\
\hline Effects & $<1$ Million & 307 & 68.2 \\
\hline & $\begin{array}{l}1-3 \\
\text { Million }\end{array}$ & 110 & 24.4 \\
\hline & $>3$ Million & 33 & 7.3 \\
\hline
\end{tabular}

The Effect of Age, Experience and Type of Work on the Quality of Life of Construction Workers in Indonesia.

- The Effect of Age on the Quality of Life of Construction Workers in Indonesia

Using One-Way ANOVA and conducting the Levene test to determine the variance-covariance homogeneity matrix explains that age has no effect on the quality of life of construction workers in Indonesia, $F(2,447)=0,812$ dan $p=0,445(p>0,05)$. 
- The Effect of Experience on the Quality of Life of Construction Workers in Indonesia

Stating that experience has no effect on the quality of life of construction workers in Indonesia, $F(2,447)=0,266$ and $p=0,766$ ( $p>0,05)$.

- The Influence of Type of Work on the Quality of Life of Construction Workers in Indonesia

The type of work does not affect the quality of life of construction workers in Indonesia, $\mathrm{F}$ $(2,447)=2,916$ and $p=0,055(p>0,05)$.

- The Effect of Income on the Quality of Life of Construction Workers in Indonesia Stating that income does not affect the quality of life of construction workers in Indonesia, $F$ $(2,447)=1,609$ and $p=0,201(p>0,05)$.

The Effect of Occupational Safety, Health and Work Accidents on Increasing Skills for Construction Workers.

By using multiple aggression analysis. Stating that work accidents affect 8.5 percent $(B=0.213$, $t=5,261$, sig $=0,000$ and $R 2=0.085$ ) and occupational health affects 3.4 percent ( $B$

$=0.141, t=4,150$, sig $=0,000$ and $R 2=0.199$ ) to improve construction worker skills.

The Effect of Work Safety, Occupational Health, Work Accidents and Worker Skills on the Quality of Life of Construction

It shows that work safety with $(B=-0.001, t=-0.021$, sig $=0.983)$,

occupational health with $(B=0.309, t=6.899$, sig $=0.000)$, work accidents with $(B=0.089, t$ $=1.654$, sig $=0.099)$ and

Worker Skills with $(B=0.0235, t=3.826$, sig $=0.000)$. For all sig numbers with a value of more than 0.05 , this indicates that the independent variable has no effect (safety and accidents) on the variable quality of life of construction workers. Meanwhile, the sig variable with a value below 0.05 indicates that the independent variable has an effect (Health and Skills) has an effect on the quality of life for construction workers.

1. The Relationship of Work Safety Variables to the Quality of Life of Construction Workers.

Pearson correlation analysis with a value of $r=-0.007$, sig $=0.890, p>$

0.05 . This shows that there is no relationship between work safety factor variables and the quality of life of construction workers.

2. The Relationship of Occupational Health Variables to the Quality of Life of Construction Workers

Pearson correlation analysis with a value of $r=0.377$, sig $=0.000, p<0.05$. This shows that there is a relationship between occupational health factor variables with the quality of life of construction workers and the strength of the relationship is weak. 
SCIENCES

Vol. 10, No. 1, 2020, E-ISSN: 2226-3624 @ 2020 HRMARS

3. The Relationship of Work Accident Variables to the Quality of Life of Construction Workers

Pearson correlation analysis with a value of $r=0.208$, sig $=0.000, p<0.05$. This shows that there is a relationship between work accident factor variables and the quality of life of construction workers and the strength of this relationship is weak.

4. The Relationship of Work Accident Variables to the Quality of Life of Construction Workers.

Pearson correlation analysis with a value of $r=0.208$, sig $=0.000, p<0.05$. This shows that there is a relationship between work accident factor variables and the quality of life of construction workers and the strength of this relationship is weak.

5. The Relationship of Worker Variable Skills to the Quality of Life of Construction Workers.

Pearson correlation analysis with a value of $r=0.277$, sig $=0.000, p<0.05$. This shows that there is a relationship between the variable worker skills factor and the quality of life of construction workers and the strength of this relationship is weak.

6. Relationship of Work Safety, Occupational Health, Work Accidents, Occupational Health and Worker Skills on Worker Quality of Life

This relationship shows the findings of the Pearson correlation analysis for occupational health (value $r$

$=0.377$, sig $=0.000$ ), worker skills (value $r=0.277$, sig $=0.000$ ), work accidents (value $r=0.208$, sig $=0.000$ ) and work safety (the value of $r=-0.007$, sig $=0.890$ ). This shows that there is a relationship between occupational health factors, worker skills and work accidents with the quality of life of construction workers and the strength of the relationship is weak. However, there is no relationship between work safety factor variables and the quality of life of construction workers.

\section{Conclusion}

This study involved a total of 450 respondents of construction workers in Indonesia. This study discusses findings that have been analyzed using descriptive statistical analysis, One-Way Analysis of Variance (ANOVA), Analysis of Correlation Techniques and multiple regression analysis. Descriptive statistical analysis that has been conducted found that workers 'perspectives on occupational health, occupational accidents, worker skills and workers' quality of life are at a high level. Meanwhile, the employee's perspective on job security is at a high enough level. Furthermore, the One-Way ANOVA analysis also shows that there is no influence of age, experience and type of construction work (structure, architecture, mechanical electricity) on the quality of life of construction workers in Indonesia. Multiple regression analysis also found that occupational accidents and occupational health have an effect on the improvement of construction workers' skills. This analysis also shows that the health of workers and workers' skills affects the quality of life of construction workers. Pearson correlation analysis also found that the relationship between the variables of occupational health factors, workers' skills and work accidents on the quality of life of construction workers and the strength of the relationship was weak. However, there is no relationship between work safety factor variables and the quality of life of construction workers.

This study can provide input on the situation of construction industry workers in order to improve time efficiency and quality of work in various aspects, especially those related to work safety, occupational health, emergencies, skills / skills and quality of life of construction workers. Besides, it can be used by the government as input to formulate policies and 
SCIENCES

Vol. 10, No. 1, 2020, E-ISSN: 2226-3624 @ 2020 HRMARS

regulations in the construction industry to ensure better development throughout Indonesia in the direction of a "zero accident". Other than that, findings from this study can be used to get an overview of the welfare pattern of construction workers and to sort workers in the construction industry so that they can be grouped into groups and last but not least, this study also makes academic contributions to further research related to the construction industry sector.

\section{References}

Byrne, B. M. (2010). Structural equation modeling with Mplus. Basic concepts, applications, and programming. New York: Routledge. Chapter $7 \mathrm{HIm}$ 194-197.

Christina, W. Y., Djakfar, L., Dan Thoyib, A. (2012). Pengaruh Budaya Keselamatan Dan Kesehatan Kerja(K3) Terhadap Kinerja Proyek Konstruksi. Jurnal Rekayasa Sipil/Volume 6, No. 1 - 2012 ISSN 1978 -5658. HIm 85-95

Chua, Y. P. (2009). Advanced research statistics: Univariate and multivariate tests. Shah Alam: McGraw-Hill Education.

Coakes, S. J. (1999). SPSS Analysis without anguish. Australia: Wiley \& Sons Ltd. Vol. 18. HIm 56-58.

Cohen, J. (1988). Statistical power analysis for the behavioral sciences. Hillslade, NJ: Erlbaum. Creswell, J. W. (2002). Educational research: planning, conducting and evaluating quantitative and qualitative research. Upper Saddle River, New Jersey: Merill Prentice Hall.

Elphiana E. G., Yuliansyah, M. D., Dan Zen, M. K. (2017). Pengaruh Keselamatan Dan Kesehatan Kerja Terhadap Kinerja Pekerja Pt. Pertamina Ep Asset 2 Prabumulih. Jurnal Ilmiah Manajemen Bisnis Dan Terapan Tahun XIV No 2, Oktober 2017.HIm 103-118

Fathoni, A. (2008). Organisasi dan Manajemen Sumber Daya Manusia. Jakarta: Rineka Cipta.

Gay, L. R., \& Airasian, P. (2003). Educational research: competencies for analysis and application. Upper Saddle River, New Jersey: Pearson Education Inc. Edisi 7, 2003.

Gay, L.R. (1996). Educational research: competencies for analysis and application. Upper Saddle River, New Jersey: Prentice-Hall Inc. Edisi 5, 1996.

Hargiyarto, P. (2011). Analisis Kondisi Dan Pengendalian Bahaya Di Bengkel/Laboratorium Sekolah Menengah Kejuruan. Jurnal Pendidikan Teknologi dan Kejuruan, Vol. 20, No. 2, Oktober 2011.HIm 203-209.

Hidayat, N., Dan Wahyuni, I. (2016). Kajian Keselamatan Dan Kesehatan Kerja Bengkel Di Jurusan Pendidikan Teknik Sipil Dan Perencanaan Fakultas Teknik UNY. Jurnal Pendidikan Teknologi dan Kejuruan. Vol. 23 No. 1, Mei 2016. HIm 3-8.

Kartikasari, R. D., Dan Swasto, B. (2017). Pengaruh Keselamatan Dan Kesehatan Kerja Pekerja Terhadap Kinerja Pekerja. Jurnal Administrasi Bisnis (JAB)|Vol. 44 No.1 Maret 2017. HIm 7-10.

Konting, M. M. (2000). Kaedah penyelidikan pendidikan. Kuala Lumpur: Dewan Bahasa dan Pustaka. Edisi 3, 2000. HIm 77- 79.

Paramita, C. C. P., Dan Wijayanto, A. (2012). Pengaruh Keselamatan Dan Kesehatan Kerja Terhadap Prestasi Kerja Pekerja Pada Pt. PIn (Persero) Apj Semarang. Jurnal Administrasi Bisnis Volume I Nomor 1 September 2012. HIm 11-15.

Rumawas, W. (2012). Usulan Penelitian Implementasi Program Jaminan Sosial Tenaga Kerja Terhadap Kecelakaan Kerja Pekerja/Buruh, dari UNSRAT Manado. Vol. 1 No. 1. HIm 51- 66.

Singgih, S. (2020). Panduan Lengkap SPSS 26. Jakarta: PT. Elex Media Komputindo. 